\title{
Immunocytochemical Demonstration of Catechol Methyltransferase in Candida tropicalis
}

\author{
By JOSEPH VESER, ${ }^{1 *}$ RAINER MARTIN ${ }^{2}$ AND HELMUT THOMAS ${ }^{1}$ \\ Abteilung Physiologische Chemie ${ }^{1}$ and Sektion Elektronenmikroskopie ${ }^{2}$, Universität Ulm, \\ D-7900 Ulm, Federal Republic of Germany
}

(Received 3 February 1981)

Catechol methyltransferase ( $S$-adenosyl-L-methionine:catechol $O$-methyltransferase; EC 2.1.1.6) was localized immunocytochemically in the yeast Candida tropicalis by the unlabelled antibody enzyme method, involving soluble peroxidase-antiperoxidase complex. Immunoreactivity was detected by light and electron microscopy in the outer layer of the cell wall and at the plasma membrane. The possible function of the methyltransferase in $C$. tropicalis is discussed.

\section{INTRODUCTION}

Catechol methyltransferase (COMT; $S$-adenosyl-L-methionine:catechol $O$-methyltransferase; EC 2.1.1.6) catalyses the transfer of a methyl group from $S$-adenosyl-L-methionine to one of the phenolic hydroxyl groups of a variety of catecholamines and other biogenic catechols (Axelrod, 1966; Axelrod \& Tomchick, 1958). Numerous investigators have demonstrated catechol methyltransferase in various animal tissues and cells (for review, see Guldberg \& Marsden, 1975). Activity of $O$-methyltransferases has also been detected in plants (Finkle \& Masri, 1964; Finkle \& Nelson, 1963a,b), and recently, catechol methyltransferase activity was found in several strains of the facultative pathogenic yeast Candida (Müller-Enoch et al., 1976). The purification of methyltransferase from Candida tropicalis (Veser et al., 1979) allowed the production of a potent and specific antiserum to this enzyme and its immunological characterization (Veser \& Thomas, 1980).

As a first step towards the elucidation of the functional role of the yeast enzyme we have examined the subcellular localization of the enzyme in the unfractionated cell. Decompartmentation of the enzyme was largely avoided by fixation: we applied an enzyme immunocytochemical method at the light and electron microscope level on deplasticized sections.

\section{METHODS}

Chemicals. Anti-rabbit IgG (swine) (a-rbIgG) and the soluble complex of horseradish peroxidase-antihorseradish peroxidase (rabbit) (PAP) were obtained commercially (Dako, Boehringer Ingelheim Diagnostika, Garching-München, F.R.G.). All other materials used were analytical grade.

Organism and growth. Cultures of Candida tropicalis CBS 94 were incubated in a nutrient medium (Sabouraud dextrose broth; $2 \%, \mathrm{w} / \mathrm{v}$ ) in a laboratory shaker at $30^{\circ} \mathrm{C}$ for $2 \mathrm{~d}$.

Antibody preparation and specificity. Preparation of affinity-purified catechol methyltransferase from $C$. tropicalis and immunological procedures for production of DEAE-Sepharose CL-6B purified anti-catechol methyltransferase-IgG (a-COMT-IgG) were performed as described previously (Veser \& Thomas, 1980).

Cell fixation procedure. The yeasts were sedimented by centrifugation at $3000 \mathrm{~g}$ and pellets were fixed in one of the following fixatives. (1) $4 \%(\mathrm{w} / \mathrm{v})$ paraformaldehyde in $0.1 \mathrm{M}$-sodium cacodylate buffer, $0.5 \%(\mathrm{v} / \mathrm{v})$ glutaraldehyde, $\mathrm{pH} 7 \cdot 3$, fixation time $1 \mathrm{~h}$; this material was embedded without osmification for immunocytochemistry. (2) $3.5 \%(\mathrm{v} / \mathrm{v})$ glutaraldehyde in $0.1 \mathrm{M}$-sodium phosphate buffer, $\mathrm{pH} 7.3$, fixation time $2 \mathrm{~h}$; this material was used for normal electron microscopy. After fixation the pellets were washed in PBS [0.01 M-sodium 
phosphate buffer, $0.9 \%(\mathrm{w} / \mathrm{v})$ sodium chloride, $0.05 \%(\mathrm{w} / \mathrm{v})$ sodium azide, $\mathrm{pH} 7.3 \mathrm{l}$ and postfixed in $2 \%(\mathrm{w} / \mathrm{v})$ osmium tetroxide in $0.1 \mathrm{M}$-sodium phosphate buffer, for $1 \mathrm{~h}$.

All samples were dehydrated in a graded series of ethanol and propylene oxide and embedded in Epon 812 .

Immunocytochemistry for light microscopy. Semi-thin sections $(0.5 \mu \mathrm{m})$ were attached to glass slides on a hot plate $\left(90^{\circ} \mathrm{C}\right.$, for $\left.30 \mathrm{~min}\right)$. Resins were removed from the sections with sodium methoxide $(50 \mathrm{~s})$ and the sections were cleaned in methanol/benzene ( $1: 1$, by vol.), acetone and distilled water (Mayor et al., 1961). The unlabelled antibody enzyme method was applied according to Sternberger et al. (1970), as described previously (Weber $e t$ al., 1978).

The incubation steps were as follows: short rinse in PBS; swine normal serum (1:30) for 10 min; PBS rinse; primary antibodies (a-COMT-IgG) at dilutions of $1: 200-1: 1000$ for $18 \mathrm{~h}$ at $4{ }^{\circ} \mathrm{C}$; PBS rinse; a-rbIgG $(1: 25-1: 100)$ for $10 \mathrm{~min}$; PBS rinse; PAP $(1: 50)$ for $10 \mathrm{~min}$; rinse in $0.05 \mathrm{M}$-Tris/ $\mathrm{HCl}$ buffer $(\mathrm{pH} \mathrm{7.6)}$; 3,3-diaminobenzidine $(10 \mathrm{mg}$ per $50 \mathrm{ml})$ in $0.05 \mathrm{M}$-Tris/ $\mathrm{HCl}$ buffer plus $1 \% \mathrm{H}_{2} \mathrm{O}_{2}(125 \mu \mathrm{l}$ per $50 \mathrm{ml})$ for $10 \mathrm{~min}$ in the dark. After dehydration, the sections were mounted in Depex and viewed with phase-contrast optics.

Immunocytochemistry for electron microscopy. Sections about $80 \mathrm{~nm}$ thick were cut and collected on Formvarand carbon-coated nickel grids. In order to expose the antigenic material the Epon was partially removed from the sections by immersing the grids for $10 \mathrm{~s}$ in sodium methoxide (Mayor et al., 1961) diluted 1:3 with methanol/benzene $(1: 1$, by vol.). Samples were then washed in methanol/benzene $(1: 1$, by vol.), acetone and distilled water. The staining schedule consisted of the following steps: incubation with swine normal serum $(1: 30)$ for $5 \mathrm{~min}$; primary antibodies (a-COMT-IgG) at dilutions of $1: 200-1: 1000$ in PBS for $48 \mathrm{~h}$ at $4{ }^{\circ} \mathrm{C}$; short rinse in PBS; swine normal serum for $5 \mathrm{~min}$; a-rbIgG $(1: 20)$ for $10 \mathrm{~min}$; PBS rinse; swine normal serum for 5 min; PAP (1:40) for $10 \mathrm{~min}$; short rinse in $0.05 \mathrm{M}$-Tris/ $\mathrm{HCl}$ buffer $(\mathrm{pH} 7.6) ; 3,3$-diaminobenzidine $(10 \mathrm{mg}$ per $50 \mathrm{ml})$ in $0.05 \mathrm{M}$-Tris/ $\mathrm{HCl}$ buffer plus $1 \% \mathrm{H}_{2} \mathrm{O}_{2}(125 \mu \mathrm{l}$ per $50 \mathrm{ml})$ for $3 \mathrm{~min}$ with gentle stirring; rinse in a large volume of distilled water with vigorous stirring; osmium tetroxide $(2 \%, \mathrm{w} / \mathrm{v}$, in distilled water) for $15 \mathrm{~min}$. The sections were examined in a transmission electron microscope with a precooled specimen stage at $80 \mathrm{kV}$.

Controls. (1) Replacement of the primary antibodies (a-COMT-IgG) by normal rabbit serum (preimmunization serum). (2) Incubation with COMT-preabsorbed a-COMT-IgG: $24 \mathrm{~h}$ before the start of the immunocytochemical staining procedures affinity purified COMT $\left(0.1 \mathrm{mg} \mathrm{ml}^{-1}\right)$ was added to the antibody solution at $1: 200-1: 1000$ $(\mathrm{v} / \mathrm{v})$. (3) Incomplete immunocytochemical schedule, omitting the a-COMT-IgG, for detection of endogenous peroxidase activity.

\section{RESULTS}

\section{Light microscopy}

COMT-immunoreactivity resided in the periphery of the cells, presumably in the cell wall and/or plasma membrane (Fig. 1a). A dense ring of reaction product surrounded most cells. In some of them this ring appeared as a double-layer. The immunoreactivity was sharply limited towards the extracellular space and towards the cytoplasm; cytoplasmic or nuclear immunoreactivity could not be detected. After preabsorption of the anti-COMT serum with affinity-purified antigen, immunostaining was completely blocked. In other control experiments in which preimmunization serum was applied instead of the anti-COMT-IgG fraction, staining was also absent (Fig. 1b). Non-specific background staining could be dramatically reduced by preincubation with swine normal serum $(1: 30)$ and by application of highly diluted $(1: 200-1: 1000)$ specific hyperimmune serum. Endogenous peroxidase activity has not been detected.

\section{Electron microscopy}

More precise, subcellular localization of COMT-immunoreactivity was possible with the use of ultra-thin sections and electron microscopy (Fig. 2). Electron-opaque polymerized 3,3-diaminobenzidine chelated with reduced osmium tetroxide was accumulated in two thick lines, the more pronounced line at the outer layer of the yeast cell wall and a thinner line in the area of the plasma membrane (Fig. $2 a, c$ ). The staining was not uniformly distributed, especially in the septum region of dividing cells. In a smaller number of cells non-specific background staining was dispersed between the two peripheral lines and over cytoplasm and nucleus. Immunostaining was absent when preimmunization serum (Fig. $2 b$ ) or antigen- 

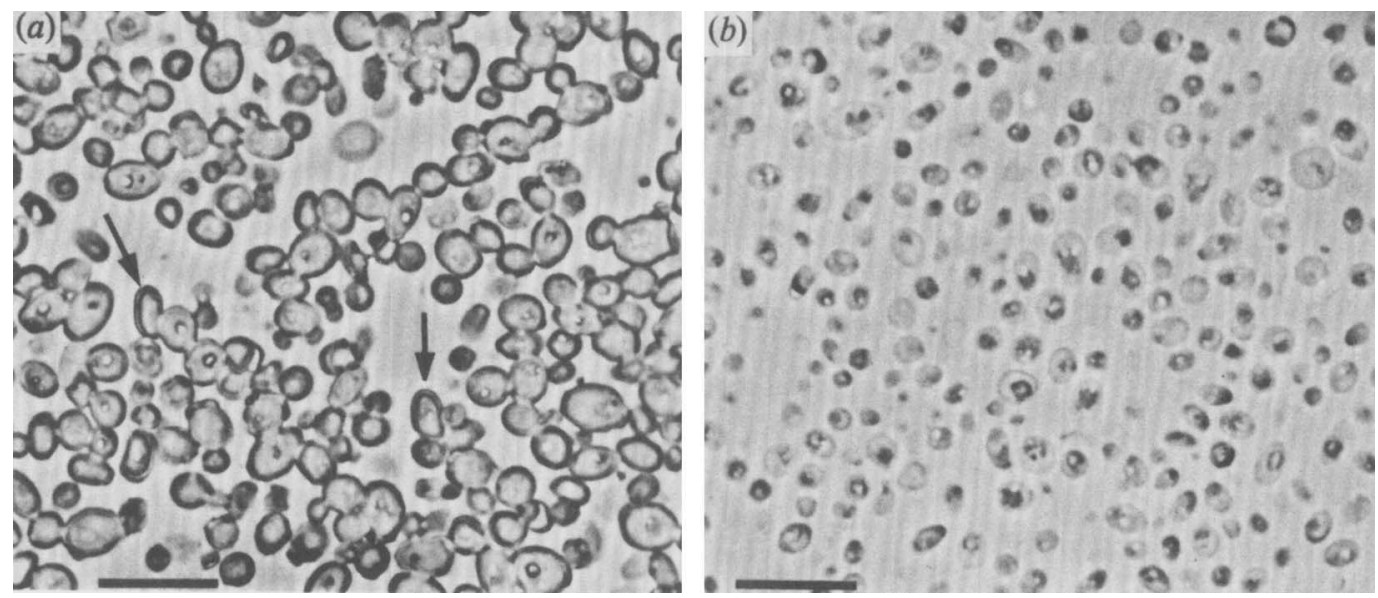

Fig. 1. (a) Phase-contrast light micrograph of a $0.5 \mu \mathrm{m}$ thick section through $C$. tropicalis cells showing COMT-immunoreactivity in the cellular periphery; the arrows point to areas in which the immunoreactivity appears to be resolved into two distinct lines. (b) A control section treated with preimmunization serum. The bar markers represent $10 \mu \mathrm{m}$.

preabsorbed COMT-antibodies were applied. In conventionally fixed and contrasted yeast cells (Fig. $2 d$ ), opaque material in the peripheral cell wall and at the plasma membrane coincided with the immunoreactivity location.

\section{DISCUSSION}

Several plasma membrane- and wall-associated enzymes in yeasts have been described. Most of them are hydrolases such as $\beta$-D-fructofuranosidase (invertase), melibiase, glucanases (1,3- $\beta$-, 1,6- $\beta$-), aryl- $\beta$-glucosidase, glucamylase ( $\beta$-) (for review, see Lampen, 1968), 1,4- $\beta$-D-xylanase (Notario et al., 1979) and acid phosphatase (McLellan \& Lampen, 1963). In addition to these hydrolytic enzymes, an external catalase (Lampen, 1968), a mannosyl transferase (Elorza et al., 1977) and a $\beta$-glucan synthase (López-Romero \& Ruíz-Herrera, 1978) were found to be constituents of the yeast cell wall. The transferase and the synthase are involved in the biosynthesis of mannans and $\beta$-glucans, respectively.

Evidence for the occurrence of these enzymes in the periphery of the cell was deduced usually from examination of distinct cell fractions produced by mechanical disruption techniques, from investigations with whole cells permeabilized by treatment with ethanol/ toluene (in situ) (Notario et al., 1979) or from utilization of an autolytic enzyme system induced by organic solvents (Arnold, 1972). Further information on wall-associated enzymes was gained by use of reagents incapable of penetrating the cell membrane (Kaplan, 1965), and by application of complex mixtures of enzymes from the digestive tract of the snail, capable of releasing cell wall enzymes by dissolving wall constituents.

Amongst the few studies of wall-bound enzymes in the intact cell, Pugh \& Cawson (1975) described methods for the cytochemical localization of phospholipase and lysophospholipase. Using immunofluorescence techniques, Tkacz \& Lampen (1973) showed incorporation of invertase in the surface of growing Saccharomyces cells. Immunocytochemical methods involving PAP complexes are well suited both for light and electron microscopy. We could not demonstrate endogenous peroxidase activity. Seligman et al. (1968) described peroxidase activity in mitochondrial cristae from $C$. albicans, but not in the cell wall or plasmalemma, after rather long incubation. 

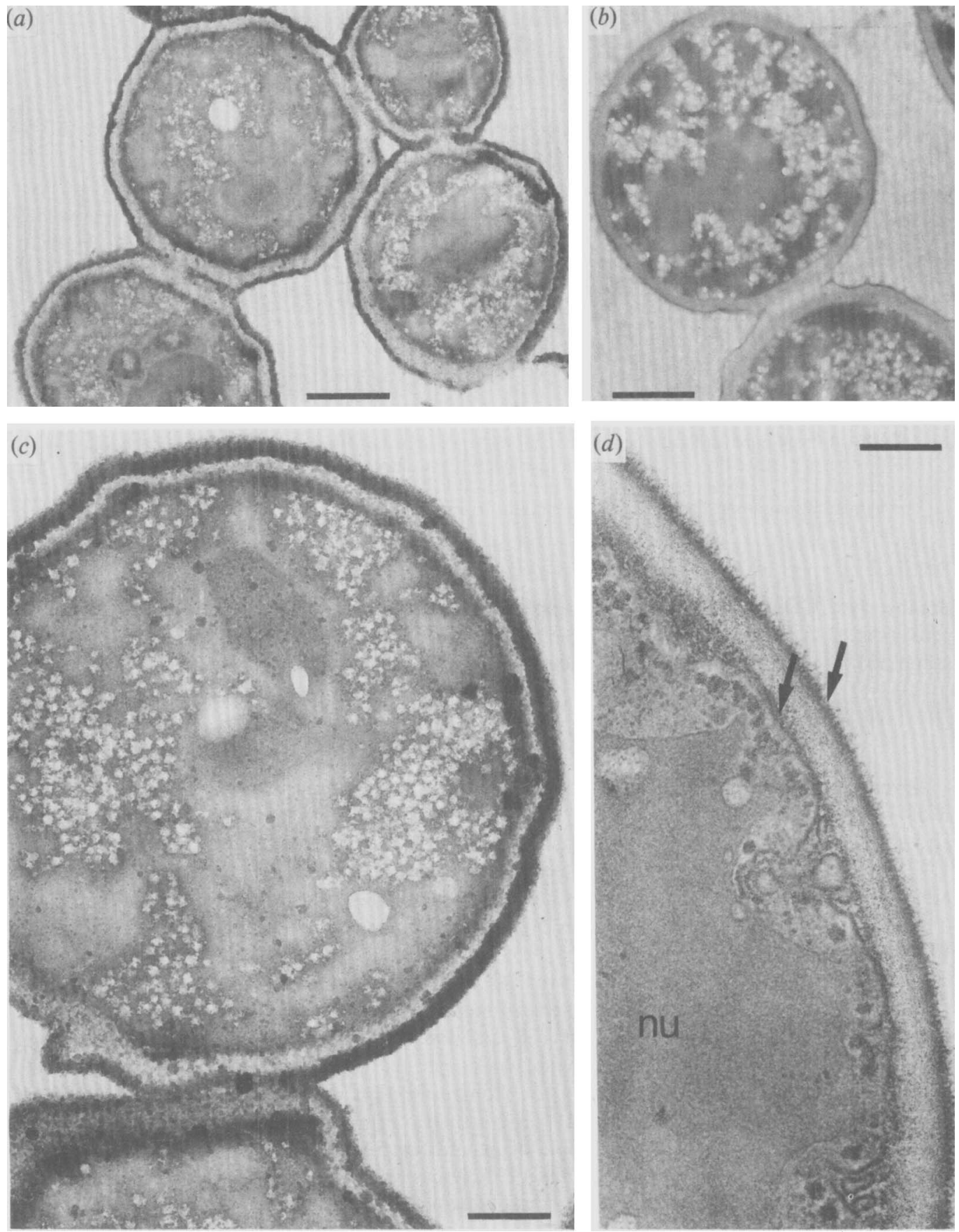

Fig. 2. $(a, c)$ Electron micrographs of sections through $C$. tropicalis cells from which the resin had been removed prior to incubation with anti-COMT hyperimmune serum. The immunoreactive PAP complexes are accumulated in two distinct peripheral lines. Fine holes are due to procedures for the removal of Epon. (b) A control section treated with preimmunization serum. (d) A conventional electron micrograph of glutaraldehyde-fixed material: the arrows point to the wall and membrane area at which COMT-immunoreactivity has been localized (nu, nucleus). The bar markers represent $1 \mu \mathrm{m}$ in (a) and $(b), 500 \mathrm{~nm}$ in $(c)$ and $250 \mathrm{~nm}$ in $(d)$. 
The immunocytochemical evidence for location of catechol methyltransferase in the wall of C. tropicalis seems to contradict our observation that about $90 \%$ of the enzyme was recovered in the $100000 \mathrm{~g}$ supernatant after disruption of the yeast by mechanical homogenization. The assumption that this enzyme is not covalently bound to a wall constituent, but rather is held in place by hydrogen bonds or other hydrophilic forces could be an explanation for this observation.

Cells in the process of separating stained weakly in the septum region. This would be an indication that the enzyme appears rather slowly in the outer layer of the newly formed wall.

The functional role of methyltransferase in the cell wall and the membrane of $C$. tropicalis is unclear. The enzyme might be involved in methylation reactions of foreign substrates so enhancing the lipophilic character of these compounds and their ability to cross the wall and cell membrane.

\section{REFERENCES}

ARNOLD, W. N. (1972). The structure of the yeast cell wall. Journal of Biological Chemistry 247. 11611169.

Axelrod, J. (1966). Methylation reactions in the formation and metabolism of catecholamines and other biogenic amines. Pharmacological Reviews 18. 95-113.

Axelrod, J. \& Tomchick, R. (1958). Enzymatic $O$-methylation of epinephrine and other catechols. Journal of Biological Chemistry 233, 702-705.

Elorza, M. V., Larriba, G., Villanueva, J. R. \& SENTANDREU, R. (1977). Biosynthesis of the yeast cell wall: selective assays and regulation of some mannosyl transferase activities. Antonie van Leeuwenhoek 43, 129-142.

FINKLE, B. J. \& MASRI, M. S. (1964). Methylation of polyhydroxy-aromatic compounds by pampas grass O-methyltransferase. Biochimica et biophysica acta 85, 167-169.

Finkle, B. J. \& Nelson, K. F. (1963a). Enzyme reactions with phenolic compounds: effect of $O$ methyltransferase on a natural substrate of fruit polyphenol oxidase. Nature, London 179, 902-903.

Finkle, B. J. \& Nelson, K. F. (1963b). Enzyme reactions with phenolic compounds: a meta- $O$ methyltransferase in plants. Biochimica et biophysica acta 78, 747-749.

Guldberg, H. C. \& Marsden, C. A. (1975) Catechol-O-methyltransferase: pharmacological aspects and physiological role. Pharmacological Reviews 27, 135-206.

KaPlaN, J. G. (1965). Action of non-penetrating heavy metals on the catalase activity of yeast cells. Nature, London 205, 76-77.

LAMPEN, J. O. (1968) External enzymes of yeast: their nature and formation. Antonie van Leeuwenhoek 34, $1-18$.

López-Romero, E. \& Ruí-Herrera, J. (1978). Properties of $\beta$-glucan synthetase from Saccharomyces cerevisiae. Antonie van Leeuwenhoek 44, 329-339.

Mayor, H. D., Hampton, J. C. \& Rosario, B. (1961). A simple method for removing the resin from epoxy-embedded tissue. Journal of Cell Biology $\mathbf{9}$, 909-910.

Mclellan, W. L., JR \& Lampen, J. O. (1963). The acid phosphatase of yeast. Localization and secretion by protoplasts. Biochimica et biophysica acta 67, 324-326.

Müller-Enoch, D., Thomas, H., Streng, W.. WildFeuer, W. \& HafERKAMP, O. (1976). $O$ Methylierung von Adrenalin. 3.4-Dihydroxybenzoesäure und 6,7-Dihydroxycumarin in Sprosspilzen. Zeitschrift für Naturforschung 31c, 509-513.

Notario, V., Villa, T. G. \& Villanueva, J. R. (1979). Cell wall-associated $1,4-\beta$-D-xylanase in Cryptococcus albidus var. aerius: in situ characterization of the activity. Journal of General Microbiology 114, 415-422.

Pugh, D. \& CAwson, R. A. (1975). The cytochemical localization of phospholipase A and lysophospholipase in Candida albicans. Sabouraudia 13. 110115.

Seligman, A., Karnovsky, M., Wasserkrug, H. \& HANKER, J. (1968). Non-droplet ultrastructural demonstration of cytochrome oxidase activity with a polymerizing osmiophilic reagent, diaminobenzidine (DAB). Journal of Cell Biology 31, 1-14.

Sternberger, L. A., Hardy, P. H., Jr, Cuculis, J. J. \& Meyer, H. G. (1970). The unlabeled antibody enzyme method of immunohistochemistry. Preparation and properties of soluble antigen-antibody complex (horseradish peroxidase-antihorseradish peroxidase) and its use in identification of spirochetes. Journal of Histochemistry and Cytochemistry 18, 315-333.

TKacz, J. S. \& Lampen, J. O. (1973). Surface distribution of invertase on growing Saccharomyces cells. Journal of Bacteriology 113, 1073-1075.

Veser, J. \& Thomas, H. (1980). Immunological studies of catechol methyltransferase from the yeast Candida tropicalis. Zeitschrift für Naturforschung 35c, 712-716.

Veser, J., Geywitz, P. \& Thomas, H. (1979). Purification and properties of a catechol methyltransferase of the yeast Candida tropicalis. Zeitschrift für Naturforschung 34c, 709-714.

Weber, E., Voigt, K. H. \& Martin, R. (1978). Pituitary somatotrophs contain (Met)enkephalin-like immunoreactivity. Proceedings of the National Academy of Sciences of the United States of America 75, 6134-6138. 